\title{
Modern management tools for sustainable development of mining enterprises
}

\author{
Alla Kasych $^{1}$, Zuzana Rowland ${ }^{2}$, and Yaroslava Yakovenko ${ }^{3 *}$ \\ ${ }^{1}$ Kyiv National University of Technologies and Design, Department of Management, 2 Nemyrovycha- \\ Danchenka St., 01011 Kyiv, Ukraine \\ ${ }^{2}$ Institute of Technology and Business, 517/10 Okružní, 37001 Ceske Budejovice, Czech Republic \\ ${ }^{3}$ Kremenchuk Mykhailo Ostrohradskyi National University, Department of Accounting and Finance, \\ 20 Pershotravneva St., 39600 Kremenchuk, Ukraine
}

\begin{abstract}
The production growth rates, the generated volumes of waste by classes of hazard, an extent of fuel and energy resources and fresh water used for coal mining, as well as the volumes of pollutant emissions into the atmosphere of Ukrainian mining enterprises have been analyzed. It has been found that achieving the decoupling (reduction of anthropogenic load) is only possible under the condition of introducing the cleaner production technologies, non-waste technologies, innovations, replacement of obsolete capital funds, and the like. Mere changes in points will not significantly affect the situation, thus, companies should develop their own approach to the sustainable development by using the frameworks as templates. The calculations have been made of the decoupling phenomenon based on the volumes of emission, the volumes of generated waste by classes of hazard and used fuel and water resources, which showed an increased anthropogenic environmental impact and economic imbalance of the mining sector. The research has been made into the use of frameworks as an auxiliary tool for the implementation by mining companies of sustainable development principles. The developed DPSIR framework, illustrated with examples from foreign experience, is conceptual in character and makes it possible to understand the cause and effect relationships of the enterprise activities impact, including mining companies, on the environment and the mechanisms of better response to the resulting consequences.
\end{abstract}

\section{Introduction}

The development of raw material industries does not correspond to the strategic task of forming an innovation model of economy. However, the mining industry is an integral part of the mineral resources sector. It plays an important role in the national economy of Ukraine due to its significant export potential. In general, the role of mining enterprises and the industry remains significant and multifaceted in modern conditions. Firstly, mining enterprises are characterized by their city-forming value. Secondly, this industry is a

\footnotetext{
${ }^{*}$ Corresponding author: yaroslavayakovenko@gmail.com
} 
consumer of goods and services of other industries in terms of mining equipment, equipment to conduct the exploratory work, the development of deposits and consumable materials, etc. Thirdly, the production of mining companies can be a raw material for other industries. Fourth, those enterprises are a source of tax revenues, replenishing the state and local budgets. In spite of the fact that the mining industry relates to the industries of the third technical and economic structure, its development in modern conditions depends on the introduction of innovations, activating creative potential of the staff and the need to reduce the negative impact on the environment without losing the dynamics of indicators. Thus, achieving the goals of sustainable development for enterprises in this sector determines the need to improve economic, social and environmental efficiency by consolidating financial, human and other resources in order to form a business model that will meet the needs of the current generation without negative consequences for the future ones.

The principles of sustainable development have become an important paradigm of the global progress in the $21^{\text {st }}$ century and define the long-range goals for the companies, including the mining ones. This is because the extraction of ores and minerals from the earth's interior has increased by 27 times over the past 100 years [1]. As for the limits of efficient extraction of many resources, they have been practically achieved. At the same time, caused by the intensive activity of mining companies, the negative impact on the environment increases, which, as noted in research [2], is manifested in the pollution of the atmosphere and the surface watercourse; flooding of territories; the use of a significant land area for the storage of rocks and waste products, and ponds - for the quarry water; ground subsidence, etc. The gradual accumulation of pollutants directly affects the health of workers and the local population. Accordingly, the goals of sustainable development determine the need to solve these already accumulated problems.

During the formation of market relations in Ukraine, mining companies have become an attractive object of privatization. However, these processes have not provided the necessary updating until now. There is an aging of the mine fund and the equipment, which leads to the drop in production volumes. Lack of investment leads to the exploitation of existing capacities exclusively, and the necessary modernization of production is postponed, which in the future may lead to the loss of target markets. Therefore, it actually threatens the sustainable development. Due to this, the main task is not only to reach the trajectory of the growth, but also to solve the accumulated problems and to ensure compliance with modern challenges, taking into account the sector peculiarities. It is precisely for enterprises in the mining industry that the task of minimizing environmental damage becomes of a particular importance. The sustainable development of the mining company is relating to the rational development of the subsoil, since the conditions for the deposits development are deteriorating over time, and mineral reserves are shrinking. Accordingly, in the process of developing the tools for ensuring the sustainable development, one should use those approaches that take into account the ecological destructiveness of anthropogenic load and the dependence of society on the state of the environment at the same time.

\subsection{The topicality of developing the management tools for sustainable development of mining enterprises}

The issue of tools for ensuring the sustainable development of mining enterprises requires researching because of:

- firstly, the traditional approaches, in particular formed within the framework of operational and strategic management, which use predominantly production indicators, should be adapted with account of the environmental aspects;

- secondly, the environmental goals in the process of the strategies substantiation for mining enterprises development are not prioritized, since owners are oriented towards 
maximizing the benefits of their activities and do not always follow the principles of the sustainable development;

- thirdly, the use of nature as the basis for the activities of this group of enterprises has its own specificity because the negative impact on the environment when using the nonrenewable resources is a more significant problem than their exhaustion and shortage.

An ecologically oriented approach should become the basis in the process of sustainable development management. Its basis is assessing the impact of economic development on the use of resources and the state of the environment [3].

Taking into account the environmental consequences, searching, approbation and adaptation of the tools for sustainable development management is an important task that is to be solved in a methodical and practical way.

The emerging problems of economic, ecological or social nature in the operation activities of mining enterprises within a certain territory in a certain way are prevented by such approach to life cycle management of the mining company as synchronous mining [4]. At the same time, some issues of differentiating the economic growth and negative impact on the environment are insufficiently studied. Besides, the side effects of the natural resources use are meant by the "negative influence", because the mining company operation activity within a certain ecosystem causes risks to the environment. In addition, attention should be paid to sector features regarding the availability of resources that do not have a great value for companies in other sectors, which are specific and strategic assets. The specific assets for mining companies are those that cannot be re-profiled and are characterized by high capital intensity, exhaustiveness, completeness and long-term use. Unlike specific ones, the strategic assets are formed with account of the peculiarities of the functioning environment and institutional constraints. Licensing of activities, private-public partnership, customs and antimonopoly regulation are among such restrictions. There is a need to delineate the tools that are suitable for application at the macro level with the ability to adapt at meso- and micro levels.

It is necessary to indicate decoupling and frameworks among the toolkits that meet the identified needs. Using them during the study of stability will allow establishing the relationship between economic growth, destructive effects on the environment and the use of natural resources.

\subsection{Improving the efficiency of sustainable development management for the enterprises: research methodology}

Features of the principles implementation of sustainable development in management practice of enterprises and phased steps in the economic, social and natural-resource spheres are being studied in the works of Ukrainian scientists, such as [5-7], proposing the detailed plans of measures and methods for quantitative assessment of the results in the field of the sustainable development. The mechanisms for ensuring the sustainable development at the micro level (enterprise) can be found in the works of [8-12].

The issue of sustainable development emphasizes the necessity to develop new approaches to nature management. Study of this issue can be found in works [2 - 4, 13, 14].

Scientists also actively explore the relationship between economic growth and environmental pressures, including eco-efficiency, environmental competitiveness, the green economy etc. Recently, the concept of "decoupling" has begun to gain popularity. Decoupling as the basis for the study of the gap between the level of economic development and anthropogenic impact on the environment is used by such Ukrainian scientists as [15-16]; foreign ones as [17-18] and others. At the same time, insufficient attention was paid to the issues of ensuring sustainable development on the example of certain industries (mining as well), which, in our opinion, is of great importance. The 
enterprises of the mining sector are characterized by the high level of integration into the economic, ecological and social environment.

The research methodology is based on the application of general scientific research methods, such as induction and deduction (to determine the essence of decoupling analysis and frameworks); interdisciplinary (for the holistic consideration of sustainable development of the mining enterprise with a reflection of all its aspects); analysis and synthesis, logical and graphical (to summarize the results and provide detailed suggestions on the use of frameworks).

The purpose of the paper is to develop methodological guidelines on the study of the sustainability of mining enterprise development using decoupling analysis and sustainability frameworks.

Ensuring sustainable development of economic systems is a complex and multifaceted process that requires constant adaptation of management mechanisms and tools at all levels of functioning.

For mining enterprises, the nature of which is determined, including their specific and strategic assets, the implementation of the concept of sustainable development is particularly important. In this context, it is necessary:

- to study the main tendencies of mining enterprise development taking into account the situation on the world market;

- to outline the key directions of implementing the theory of sustainable development for mining enterprises;

- to substantiate the possibilities of adapting the modern analytical tools such as decoupling analysis, the use of which will enable to increase the level of information provision of management decisions on sustainable development at the enterprises of the industry;

- to form a methodological basis for improving the management of sustainable development with the help of frameworks, which will enable to consider the sector features;

- to offer detailed priority measures and a set of tools in the context of ensuring sustainable development of the mining industry.

\subsection{Analysis of the trends of sustainable development of mining enterprises}

The complex, diversified and multilevel process of sustainable development determines the need for research of the industry trends first of all, the understanding of which allows to generate the necessary management tools at all levels (macro-, meso-, micro-).

Ukraine has the first place by the number of mineral deposits and their quality in Europe. According to the Institute of Environmental Economics and Sustainable Development of the NAS of Ukraine, the resource potential of our country is about 7.5 trillion dollars [19]. On the other hand, the share of natural resources per unit of GDP in Ukraine is by $2-3$ times higher (the number of harmful substances emissions, as a consequence) compared with economically developed countries, and open mining methods for obtaining the final product (up to $5 \%$ of total production) cause a significant amount of waste (slag, rocks, etc.) [20].

The importance of the mining industry in the development of the national economy is quite high: the share of the total volume of industrial products sold in recent years is 10$11 \%$, enterprises of the industry in 2017 have paid 75 billion UAH of taxes, which is more than $40 \%$ of all taxes of legal entities [21, 22], which means the importance of managing the industry development on the principles of sustainable development.

In recent years, the development of mining enterprises has been negatively affected by military activities, which led to a partial loss of the coal industry infrastructure in the East of Ukraine. As a result, the number of destabilizing factors has increased. Despite the 
increase in coal production in 2016 by $2.8 \%$, the country's dependence on the imports of certain ranks arises [23]. This problem has exacerbated the problem of sustainability of the development not only in the industry, but in the national economy as a whole, because it was added to the shortage of other fuel and energy resources, oil and gas.

For countries rich in natural resources, including Ukraine, the mining industry is one of the key factors of social development and economic growth. However, maximizing all the benefits can be provided with a responsible approach to ensuring sustainable development of the industry on a modern technological basis.

In other words, the whole mining industry, unlike oil and gas, is less related to the problem of exhausting the resources of the industry, the enterprises face environmental and technological challenges and risks, solution of which requires more financial resources. So, according to the Ministry of Ecology and Natural Resources of Ukraine [24], for example, in 2015 the total cost in the industry related to environmental protection has increased by $55.7 \%$.

The riskiness of the operation of enterprises in the industry is conditioned by the lack of guarantees of the payback of exploration works and the correspondence of the volumes of the planned and actual extraction. The global trend today is an increase in opencast mining, the reasons for which are [12] the increase in the cost of underground mining and the use of low-grade ore through the introduction of more efficient technologies. In addition to this, technological problems of the activity may arise due to inadequate study of the mining and geological characteristics of the extraction area, resulting in additional costs for re-research and occupational safety, in order to avoid accidents and injuries.

The synthesis of the conducted researches, including those, made through the prism of the concept of sustainable development, allows distinguishing the following main tendencies:

- the role of the mining industry in the development of the national industry not only remains important, but also increases. It is giving it virtually strategic significance in modern terms, but the dynamics of production volumes is unstable;

- natural conditions despite the high level of exhaustion serve as a powerful potential that can be expanded through new geological exploration and expansion of investment programs;

- the predominance of economic feasibility over other components of sustainable development, which means ignoring of environmental and social issues due to the low level of investment activity in the industry.

The complexity of managing the sustainability of the mining enterprises development is because the industry has a high level of globalization. Accordingly, monitoring the global economic processes, the dynamics of economic growth, the situation in the stock markets, the dynamics of prices and their interdependence are very important.

Thus, despite a certain recovery in production in $2015-2016$, the prices of products in the industry have not yet returned to the pre-crisis level in 2011 [25]. The instability of prices for products of mining enterprises causes instability and other systemic economic processes. As noted earlier, the mining industry experienced a worldwide unprecedented containment of capital expenditures (during the 2015 - 2016 years). To solve the situation, companies try to optimize cash flows or even sell assets.

The confirmation of the instability of the industry development is the fact that the cost of geological exploration in the world in 2016 amounted to 7.2 billion dollars, which was only one third of the record amount of $\$ 21.5$ billion dollars in 2012 [26]. This fact testifies to the general tendency of financing less risky projects and reorientation of investments to technological upgrades.

Such a careful and cost-effective approach means that mining companies continue to develop the projects implemented on the basis of improving productivity of the existing production. 
At the same time, it is impossible not to take into account the investments in environmental projects, which involve the development and implementation of environmental measures in the mining region. Environmental protection activities include preliminary degassing of geological structures, improvement of the quality of dust collectors, ensuring safe removal of mineralized waters and utilization of waste, etc. Such measures provide mining companies with far more advantages than simply reducing costs. By reducing the scale of their activity consequences for the environment, it is easier to regain the public trust.

Thus, the development of the mining industry in the world occurs in the following conditions:

- volatility of prices;

- reducing the cost of exploration work;

- increasing of opencast mining;

- strengthening the environmental protection measures.

The world market situation has a significant impact on the development of the mining industry in Ukraine, defining not only the dynamics of development, but also influencing its factors.

In general, there is a discrepancy with global trends. Therefore, the risks of sustainable development require the systematic management.

\section{New approaches to sustainable development of mining companies: decoupling analysis and the use of frameworks}

The development of the mining industry is mostly influenced by the unwillingness of the market to increase energy prices and insufficient diversification of their supplies; loss of infrastructure of oil-gas and coal industry; monopolization of separate segments of the energy market; low activity of modernization processes.

Under such conditions, it becomes important to search for and implement the theory of sustainable development in the practice of managing the mining companies and the search for appropriate analytical tools. Previously, the operational efficiency and sustainable development were separate, non-interlinked aspects of activity. Therefore, the sustainable development support was a prerequisite for obtaining a license for extraction. Nowadays, because of falling commodity prices, the policy of mining companies is aimed at strengthening economic positions and investing in new technologies to increase operational efficiency and better respond to changing market conditions because of the depletion of resource reserves.

Observance of the principles of sustainable development for a mining company in economic terms means long-term economic benefits for the company itself and the ecosystem around it. The benefits of maintaining a sustainable development strategy are also reflected in improving transparency and improving efficiency.

It should be noted that the activity of mining enterprises has a negative impact on the environment. Economic growth remains one of the key criteria for regional development. However, in the context of sustainable development, environmental protection and social protection are also important criteria. Since the fossils are deposited in the crust seams, in order to achieve a layer, the forests are cut down and the upper soil layers are removed, which poses a significant environmental hazard and, because of washing the coal, environment is polluted by the sludge containing toxic elements and heavy metals.

In earlier times, the interpretation of the principles of sustainable development in the mining industry was limited to controlling carbon emissions and supporting local communities. Over time, it turned out that the activities of mining companies have longterm environmental impacts, which have become more important in terms of community, 
resource and biodiversity impacts.

Nowadays the issues of reputation of mining companies are not only among those belonging to the PR sphere. A more active position in the area of corporate social responsibility allows us to improve the availability of the information provided to the better communication of the key ideas to stakeholders. In addition, in modern conditions, the mining companies are not limited to the implementation of charity, directing part of the incomes to funds that support local needs.

Local communities and regulators carry the pressure on mining companies and manifest themselves in the requirements for the disclosure of a wide range of information on environmental impacts.

There are many important initiatives to provide information about sustainable development, such as the Global Reporting Initiative (reporting is mandatory for members of the International Council on Mining \& Metals (ICMM)) and the Extractive Industries Transparency Initiative (EITI), but a common approach to reporting in the industry is still not formed.

In addition to that, there is a convergence between economic, environmental and social initiatives. For example, the use of renewable energy sources reduces operating costs, improves mining efficiency, stabilizes energy supply and reduces carbon emissions.

As the fragmentary approach to the sustainable development proved to be ineffective, the search for a basic mechanism of the sustainable development has begun, according to which the economic growth (including raw materials industries) is possible without increasing environmental risks. Thus, the phenomenon of decoupling appeared (the distinction between economic growth and the reduction of environmental pressures).

The researchers of decoupling [27-28] conclude that it can establish the causal relationships between economic growth and environmental pressures, as well as differentiate people's welfare and the efficiency of resource use.

Decoupling, as well as other indicators of ecological and economic development, was first used by the experts of the Organization for Economic Cooperation and Development (OECD) to determine the current position of the countries on the path to sustainable development. Subsequently, the decoupling analysis has become a part of the strategies of sustainable development of the EU and the world. Among the key documents, in addition to the "Indicators for measuring the gap between environmental pressures and economic growth" of the OECD [29], one should mention "The gap between the use of natural resources and the environmental effects of economic growth" by UNEP [30], which treats decoupling as a distinction between economic growth and environmental pressures, when the growth rate of economic driving force (for example, GDP) is higher than the pace of environmental pressure over a certain time span.

The decoupling system includes the following indicators [29]: climate change, air and water pollution, waste and materials use, impact on biodiversity.

Depending on the nature of the manifestation in the EU countries one distinguishes [31] resource decoupling (the tendency to use less resources per unit of economic output) and decoupling of influence (the trend of increasing production volumes when the negative impact on the environment decreases).

We will investigate how the mining industry can reduce the negative environmental impact at unchanged level of production and service delivery (resource decoupling).

In this study, we will use indicators used in the national system of statistical data for the mining industry: production of coal, metal ores and other types of products of the mining industry, as well as the amount of waste generated by hazard classes and emissions from the extraction of the listed types of raw materials.

It is important to note that other types of raw materials are not differentiated because of the need for correlation of indicators, since statistical information on emissions is given in 
the form of annual generalized indicators. At the same time, the use of fuel and energy resources, as well as fresh water for coal mining is taken into account.

\section{Results of applying modern analytical tools for managing the sustainable development of mining enterprises}

The decoupling effect occurs when the indicators that must have a correlation dependence do not have synchrony. The phenomenon of absolute decoupling is observed when the indicators of the negative impact on the environment decrease or remain unchanged against the backdrop of economic growth [15]. If the tendency to economic growth is weaker compared to increasing the ecological component, then decoupling is relative [7]. Based on this, we will investigate how the economic subsystem of the mining industry of Ukraine has evolved over the recent years in relation to the ecological one.

Table 1 shows the empirical data used in the study.

Table 1. Output data for the decoupling analysis of the mining industry in Ukraine in $2011-2016$.

\begin{tabular}{|l|c|c|c|c|c|c|}
\hline \multicolumn{1}{|c|}{ Indicator } & 2011 & 2012 & 2013 & 2014 & 2015 & 2016 \\
\hline $\begin{array}{l}\text { Gross value added in actual } \\
\text { prices; UAH mln }\end{array}$ & 85694 & 82528 & 82287 & 79120 & 95141 & 131650 \\
\hline Coal production, mln tons & 62.7 & 65.7 & 64.4 & 45.9 & 29.9 & 40.9 \\
\hline $\begin{array}{l}\text { Extraction of metal ores, mln } \\
\text { tons }\end{array}$ & 303.9 & 307.7 & 324.5 & 314.0 & 297.1 & 290.9 \\
\hline $\begin{array}{l}\text { Extraction of other types of } \\
\text { products of mining industry, } \\
\text { thousand tons }\end{array}$ & 7881.0 & 7919.0 & 7369.5 & 4178.8 & 3773.0 & 4055.0 \\
\hline $\begin{array}{l}\text { Volumes of forming the waste } \\
\text { of I - IV classes of hazard, } \\
\text { thousand tons }\end{array}$ & 330301.9 & 338025.0 & 341363.2 & 267506.1 & 232642.4 & 217907.8 \\
\hline $\begin{array}{l}\text { including I-III classes of } \\
\text { danger }\end{array}$ & 38.6 & 39.2 & 41.5 & 39.1 & 37.6 & 30.0 \\
\hline $\begin{array}{l}\text { Emissions of pollutants into } \\
\text { the atmosphere, thousand tons } \\
\text { (total) }\end{array}$ & 856.2 & 882.4 & 921.2 & 556.8 & 490.9 & 465.4 \\
\hline $\begin{array}{l}\text { - from the extraction of hard } \\
\text { coal and brown coal }\end{array}$ & 743.3 & 772.9 & 760.1 & 424.7 & 373.7 & 342.9 \\
\hline $\begin{array}{l}\text { - from the extraction of metal } \\
\text { ores }\end{array}$ & 97.6 & 100.5 & 111.7 & 96.4 & 80.5 & 82.5 \\
\hline $\begin{array}{l}- \text { from the extraction of other } \\
\text { minerals and the development } \\
\text { of quarries }\end{array}$ & 1.3 & 9.0 & 12.4 & 7.9 & 8.4 & 8.6 \\
\hline $\begin{array}{l}\text { Use of fuel and energy } \\
\text { resources, thousand tons of } \\
\text { oil equivalent }\end{array}$ & 1687 & 792 & 1664 & 1562 & 1490 & 1671 \\
\hline $\begin{array}{l}\text { Use of fresh water for coal } \\
\text { production in mln m }\end{array}$ & 57 & 56 & 51 & 33 & 24 & 29 \\
\hline
\end{tabular}

Source: $[23,32,33,34]$.

We will conduct a diagnostics of synchronicity, having considered the relationship between growth rates and pollutant emissions for each of the above extraction types, in order to determine whether there is a decoupling effect. The analysis of the above indicators and the interrelationships between them will serve to confirm or refute the presence of the decoupling effect in order to detect the laws of dynamics, to calculate the chain growth rates of extraction and emissions of pollutants into the atmosphere. The application of a chain rates of the growth in this case implies that we determine the ratio of indicators of each subsequent year to the previous one, the value of which is taken as $100 \%$. 
Accordingly, the calculations are carried out in comparison with the previous period, rather than the selection of the first period in the sample as the basic one. The results of calculations are given in Table 2 .

Table 2. Chain rates of the extraction growth and pollutants emission into the atmosphere by Ukrainian mining enterprises in 2012 - 2016, in \% compared to the previous period.

\begin{tabular}{|l|c|c|c|c|c|}
\hline \multicolumn{1}{|c|}{ Indicator } & 2012 & 2013 & 2014 & 2015 & 2016 \\
\hline Coal (production) & 104.78 & 98.02 & 71.27 & 65.14 & 136.66 \\
\hline Coal (emissions) & 104 & 98.34 & 55.87 & 87.99 & 91.76 \\
\hline Metal ores (production) & 101.25 & 105.46 & 96.76 & 94.62 & 97.9 \\
\hline Metal ores (emissions) & 102.97 & 111.14 & 86.3 & 83.51 & 102.48 \\
\hline $\begin{array}{l}\text { Other products } \\
\text { (production) }\end{array}$ & 100.48 & 93.06 & 56.7 & 90.29 & 107.47 \\
\hline $\begin{array}{l}\text { Other products } \\
\text { (emissions) }\end{array}$ & 692.31 & 137.78 & 63.71 & 106.33 & 102.38 \\
\hline
\end{tabular}

Source: $[17,26,30,31]$.

As far as seen from Table 2, the amount of emissions decreased in the selected period for the study and there was a slowdown in the growth rates of coal, ore and other products production $(2012-2013)$. The rapid growth of extraction, especially during the period of 2015 - 2016, when coal production increased by almost $37 \%$ and other types of products by more than $7.4 \%$ has led to an increase in emissions even more. This suggests that there is a relative decoupling in the mining industry against the backdrop of anthropogenic pressure on the environment.

Now let us proceed to the direct calculation of decoupling factors. According to OECP recommendations, the calculation of the decoupling index (DI, Decoupling Index) and decoupling factor (DF, Decoupling Factor) is carried out according to the formulas:

$$
\begin{gathered}
D I=\frac{((E P / D F) \text { ending })}{((E P / D F) \text { beginning })} ; \\
D F=1-D I,
\end{gathered}
$$

where $E P$ (environmental pressure) is an anthropogenic pressure on the environment, $D F$ (driving force) are indicators of economic growth for the final (ending) and the initial one (beginning) time span.

In that cases, when the value of the decoupling factor $(D F)$ is greater than zero and shows a tendency to increase, there is a reduction in anthropogenic pressure on the environment against the backdrop of economic growth. When the value of the decoupling factor is zero it is a controversial situation. In this case, there is an equality of rates of economic growth and consumption of natural resources. This means the persistency or reduction of the rates of natural resources exhaustion, depending on the change in the size of nature capacity. If the decoupling factor is below zero and is in the dynamics of decreasing, environmental pressure increases along with economic growth.

First, it is necessary to determine the list of indicators that characterize the rates of economic growth and environmental damage. To characterize the rates of growth in the mining industry $(D F)$, we will the production volume of coal, metal ores and other types of mining products in natural meters. Such a choice is because the cost indicators depend on fluctuations in prices for products of mining enterprises. As for the environmental damage indicators $(E P)$, we will use volumes of hazardous waste generation and emissions of pollutants into the atmosphere for the calculation part. Other types of environmental 
damage caused by the operation of mining companies and the ways of their prevention will be discussed in detail later in the description of the proposed framework. Analysis of decoupling by resource factors is based on data on the use of fuel and energy resources, as well as on the use of fresh water for coal production.

The results of calculations of decoupling indicators of mining enterprises on the factors of influence on the environment and on resource factors in Ukraine for the period of 2012 2016 are shown in Table 3.

Table 3. Decoupling indicators according to the factors influencing the natural environment and resource factors in Ukraine in 2011 - 2016.

\begin{tabular}{|c|c|c|c|c|c|c|}
\hline Decoupling indicators & 2012 & 2013 & 2014 & 2015 & 2016 & $\begin{array}{l}\text { Average } \\
\text { value }\end{array}$ \\
\hline \multicolumn{7}{|c|}{ Decoupling indicators for impacts on the environment } \\
\hline Waste generation & -0.60 & -0.10 & 0.19 & 0.28 & 0.32 & 0.02 \\
\hline \multicolumn{7}{|c|}{ Emissions of harmful substances into the air } \\
\hline $\begin{array}{l}\text { from the extraction of hard and brown } \\
\text { coal }\end{array}$ & 0.99 & 0.00 & 0.22 & -0.35 & 0.33 & 0.24 \\
\hline from the extraction of metal ores & -0.03 & -0.04 & 0.09 & 0.13 & -0.05 & 0.02 \\
\hline $\begin{array}{l}\text { from the extraction of other minerals and } \\
\text { the development of quarries }\end{array}$ & -4.00 & -0.68 & 0.35 & -18.4 & 0.9 & -4.37 \\
\hline \multicolumn{7}{|c|}{ Decoupling indicators for resource factors } \\
\hline Use of fuel and energy resources & 0.52 & -1.08 & 0.00 & 0.22 & 0.37 & 0.01 \\
\hline $\begin{array}{l}\text { Use of fresh water for coal production in } \\
\text { million } \mathrm{m}^{3}\end{array}$ & -0.01 & -0.08 & -0.47 & -0.66 & -0.14 & -0.27 \\
\hline
\end{tabular}

Source: authors' calculations.

The value of most decoupling indicators is close to zero, so it is advisable to talk about the possibility of absolute decoupling. The value of the decoupling factor for the generation of waste for a given period in the industry ranged from -0.60 to 0.32 . The decoupling factor for emissions of harmful substances into the air in 2011 - 2016 was the following: from the extraction of hard and brown coal - within the range from -0.35 to 0.99 ; from the extraction of metal ores - in the range from -0.05 to 0.13 .

In terms of decoupling indicators for resource factors (as for the use of fuel and energy resources, there is also an absolute decoupling (except for 2013). At the same time the decoupling factor for the use of fresh water for coal production during the period under investigation ranged from -0.66 to -0.01 . Significant anthropogenic pressure is also observed because of other minerals extraction: the decoupling rates are in the range from 18.4 to 0.35 (relative).

The calculations show the increase in anthropogenic impact on the environment and the economic imbalance of the industry. In order to solve these problems active implementation of the principles of sustainable development in the activities of mining companies should be ensured.

Several scientific and methodological approaches (frameworks) were developed by the Organization for Economic Cooperation and Development to form integrated systems of indicators of sustainable development [35]. Frameworks characterize enterprise sustainability, reflecting processes occurring within all systems (human, nature, economics), their statics and dynamics (current status and changes over time).

The use of frameworks makes it possible to understand better the cause-effect relations between the impact of enterprises, including mining, on the environment and the mechanisms of reaction in response to the resulting consequences. The mechanism of sustainable development management in its general form is a part of an economic system that functions in a consistent manner and interacts with other mechanisms as a whole. At the same time, the process of managing sustainable development should be characterized by 
the possibility of self-regulation, which is achieved by using the regulators (economic, administrative, market, etc.).

While applying the process approach, when the mining company is considered as a network of business processes, it is possible to provide ways for sustainable development in the form of functional blocks, combined with common strategic goals and objectives. If the requirements of precision and reliability are applied to sustainability indicators (which is important for mining companies), the most optimal is the DPSIR framework, the improved form of which, based on the needs of the industry, is given in Fig. 1.

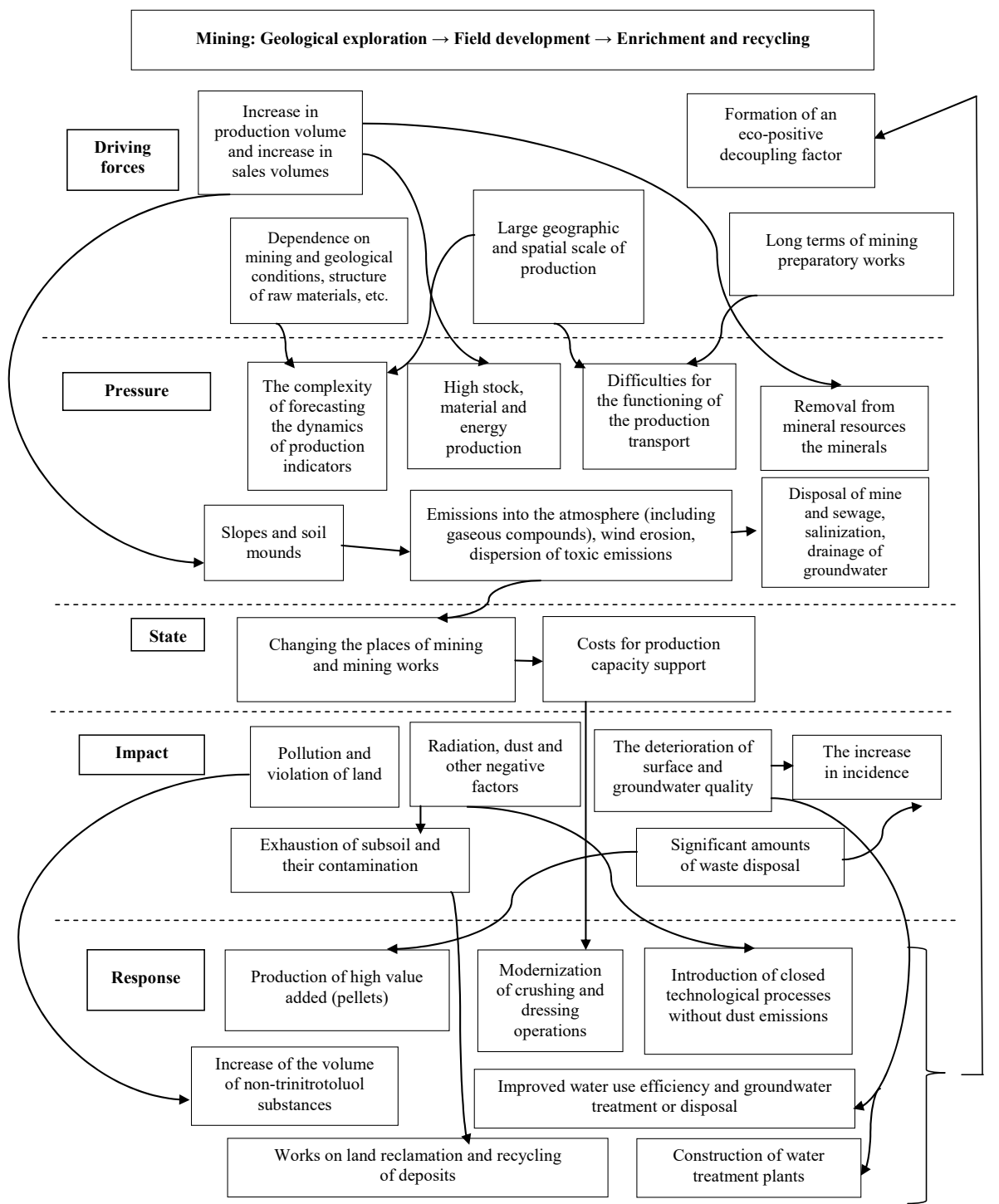

Fig. 1. DPSIR Framework for Mining Companies.

Framework "Driving forces - Pressure - State - Impact - Response model" (DPSIR model) allows us to formulate the detailed priority measures. The sequence of stages and their duration is influenced by a set of mining and geological conditions (depth of extraction, thickness and depth of layers' occurrence, etc.) and other factors: economic (the 
degree of economic risks), political (effectiveness of state policy, degree of support of the industry), social (state of social infrastructure, the presence of tension in society, etc.).

At the initial stage called "Driving forces", it is necessary to determine the current state of the object (the enterprise), as well as the goal - the necessary transformation (determining the state of stability to be achieved). Impulses are events that lead to the formation of a balance of all components of sustainable development.

This stage is important for the correct assessment of the company's starting positions in the market. During 2014-2015, when prices in the commodity market began to fall, not all companies were able to anticipate timely the period of time necessary for their recovery. However, over time, it became clear that new operating models are required to ensure sustainable business development in conditions of instability. An example is the mining company IntegraGold Corp., which searches for new potentially profitable deposits by means of the crowdsourcing method [36]. Those companies that have changed target geographic regions, diversified assets and reduced costs, now need to adapt their operating models to current conditions.

At the second stage ("Pressure"), one should assess the possibilities for reducing the potential negative impact on the natural environment.

The practical implementation of cooperation may be the application of the crowdsourcing method when the public is invited to discussion. Open industry forums give mining companies the opportunity to work with suppliers, and the so-called "hackathon" to develop intensively the necessary software. It is advisable to work together from the very beginning, so that all industry participants could benefit from the research conducted over time. The forms of such cooperation can be varied from co-financing of infrastructure projects to joint geological exploration operations. In addition, it is necessary to expand partnerships with equipment manufacturers, design and equipment providers, industry associations and educational institutions.

The following companies can serve as examples of successful cooperation [25]: Alcoa has introduced 3D printing of metal parts, which simplifies the assembly process and facilitates greater compliance of products with established specifications; Schneider Electric has introduced a maintenance strategy, which was determined by the actual technical condition of the product at the start of service that contributes to saving money and significantly reducing downtime; GE Power has introduced the creation of "twins" of spare parts in order to be able to simulate different scenarios for the equipment operation.

At this stage, it is also important to consider that the exhaustion of mineral reserves leads to the need for financial investments in the development of new deposits. In the case of placing a mining company in an undeveloped area, additional costs are required by the creation of infrastructure and additional exploration of deposits.

The third stage ("State") determines the expected impact. Reducing waste can be achieved by the use of new recycling technologies that make it possible to recycle waste. Measures to minimize waste and their planned disposal are important, but they do not completely solve the problem of pollution. The wastes of the enterprises of the mining and metallurgical complex are a source of danger because of the potential opportunity for penetration of harmful substances into the biosphere. In the aspect of nature management, ensuring the sustainable development of the mining company is to rationalize the resources used, minimize the negative impact on the environment of industrial waste and increase the environmental safety of production. Since the reclamation of territories that have undergone changes because of mining activities requires significant funds, the formation of the landscape within the field should take place in view of the need to minimize the risks of erosion and the transfer of the upper soil layer.

Pollution of the air basin because of the use of explosives during opencast mining also negatively affects yields of crops and forest condition, etc. The danger is also the release of 
methane from the developed coal seams and accumulation of mine gas in mine workings. This necessitates the constant ventilation and degassing of the concentrated gas-air mixtures.

The heaps of waste rock and leaching product of materials (tailings, sent to settling pond) should be investigated by laboratory analysis in terms of the threat to biodiversity because they may contain sulphides dangerous for phytocoenosis of the territory [37]. It is also necessary to evaluate the water-retaining ability of the soil and the presence of internal drainage.

The automation of mining operations plays an important role, which allows enterprises to analyze the arrays of collected digitized data, create a "brain centre", the site for collecting and further analysis of the collected data as the basis for monitoring planning and decision support. In practice, this can mean the transfer of short production cycles, planning and control to remote operating centers, where the sales chain is visualized and tracking the key operating indicators. It allows operative implementation of industrial improvements.

In the fourth stage ("Impact"), an important factor in stimulating the sustainable development of mining enterprises is the management of resources as a prerequisite for the equilibrium of their functioning. An example is IntegraGold Corp., which has decided to apply the principle of decentralized management, when field managers receive extended powers and are responsible for ensuring maximum environmental friendliness of production [36].

At this stage, it is important to estimate the amount of waste of enrichment (tailings) and the share of useful industrial waste, as well as the amount of actual emissions of harmful substances.

The liquidation of a mining company means not only the loss of a source of profit for the owner from an economic point of view, but also the formation of economically depressed (need for grants) and socially unstable (large-scale dismissal, migration, retraining) of the region. In the environmental sphere, there is a need for natural regeneration of the territories. There is a successful example when Teck's mining company, having closed one of its fields, turned it into a solar power plant SunMine, which is today the largest solar farm in western Canada [38].

The conservation of mines can also lead to the emergence of a new technogenic relief and deformation of the surface, which increases the cost of reclamation, as well as the migration of mine gases [39].

The compliance with the principles of stable/sustainable development will allow saving money by reducing fines for emissions and resource payments.

At the fifth stage ("Response"), there is an analysis of ways to support the achieved state of stability. Today, the ore mining and processing enterprises, formulating strategies based on sustainable development, present details of the peculiarities of the nature use, external influences, the implementation of regulatory requirements, etc. Currently, there is a tendency of internalization, when internalization costs are partially paid by society at the expense of higher prices for products [18]. As a result, cash inflows are less dependent on fluctuations in sales volumes than on demand for products. Accordingly, there are prerequisites for increasing environmental responsibility and implementation of social programs. In order to increase productivity, extraction companies should also be careful about creating a supportive work environment for their employees [40]. For example, in Australia, the RUOC is co-operating with mining companies, which is intended to contribute to a conscious reduction in the number of committed suicides [25].

The optimization of water supply is equally important. The need to increase water efficiency and preserve the safety of water resources remains one of the central environmental issues for mining companies. For the overwhelming majority of enterprises, the discharges of pollutants substantially exceed the established maximum of allowable 
discharges [23]. The companies invest in the development of mining water treatment technologies, reuse of wastewater for production needs. In addition, the options for enrichment in a dry manner that does not require water use are considered. As the metal content decreases in ore, there is an increasing need for water, so mining companies can experience water shortages. At this stage, it is important to invest in wastewater treatment (using reverse osmosis, ion exchange, membrane filtration, etc.) in order to reduce the use of fresh water. Nowadays the practice of using special sensors at the stage of ore extraction is also widespread, which makes it possible to save water and energy consumed at the stage of preparation for enrichment even before the excavation.

The organization's top-priority strategic objectives should also include the care for employees' health, taking into account the impact of this aspect on the level of employee involvement, performance, productivity, and retention of talent.

The final stage of changeover to sustainable development suggests that the economic effect of the transition to sustainable development will be to increase the investment attractiveness of the mining company and increase its pace of development. Social effect is in the growth of social stability in the territory of the enterprise placement, improvement of working conditions, staff qualification and level of remuneration. Ecological effect is in solving the problems of environment oriented nature.

The DPSIR framework developed by us for mining companies is suitable for use at the micro level.

At the same time, the following measures should be taken at the level of public administration: the elimination of trade barriers in order to ensure equal access to the markets for products; wider involvement of communities in solving environmental problems; improvement of transport infrastructure; ensuring transparency of state policy; approximation of the legal base to international standards; realization of the obligations of euro integration of Ukraine.

\section{Conclusions}

The mining complex continues to be an important component of the economy of any country. Therefore, the problem of sustainable development is relevant. The study of the features and trends of mining enterprises in Ukraine and the world shows the unstable dynamics of production, investment and modernization costs. An important direction in improving the management system at enterprises in the current environment is the implementation of the concept of sustainable development into the practice of Ukrainian enterprises, which involves not only focusing on sustainable economic performance, but also compliance of products and production with environmental standards, innovation development, and compliance with the principles of social responsibility.

During the study of the main trends in the development of enterprises in Ukraine and the world, the main factors that determine the instability of the industry are the dependence on raw material prices, technological lag, insufficient rationalization of the use of limited natural resources, the increase of anthropogenic loading on the territory within the direct influence of mining enterprises.

To improve the information provision of management solutions for sustainable development, we suggest the use of one of the most advanced analytical tools - decoupling analysis. Its practical testing on the example of the mining industry of Ukraine makes it possible to find that the growth of economic development is accompanied by a simultaneous increase in the burden on the environment, which contradicts the requirements of the concept of sustainable development. We use the following indicators of the decoupling analysis: the growth rates of extraction, waste generation by hazard classes, scale of use of fuel and energy resources and fresh water for coal production, as well as the 
emissions of pollutants into the atmosphere.

Since in Ukraine there is a significant anthropogenic load of the mining industry, it is necessary to achieve decoupling (reducing the load). This is possible with the introduction of technologies for cleaner production, non-waste technologies, innovations, replacement of obsolete fixed assets, etc.

Due to the significant influence of mining companies on the environment, there is a need to develop new approaches to sustainable development, the use of which will increase the level of information provision of management decisions. In particular, we suggest the use of frameworks as patterns, which will allow taking preventive measures aimed at strengthening the reputation, establishing the lost links and regaining trust to the industry.

The developed DPSIR framework, illustrated with examples from foreign experience, contains content blocks for the organizational subsystem and includes management and information support activities; on operation (technological and personnel support, as well as strategic planning) and a unit for geological and economic assessment of the state of the enterprise and its expected/actual impact on the natural environment.

Thanks to the frameworks application, the following measures are suggested for the implementation of the sustainable development theory for mining enterprises:

- improving the provision of labor protection and industrial safety (to make a preliminary assessment of the state of enterprise preparedness);

- raising the level of rational use of water resources (to provide water supply without discharging sewage, dehydration of slags, enrichment in a dry manner, etc.);

- improving the processing and elimination of waste products (applying the means of reducing harmful emissions, rehabilitating the territories);

- promoting socio-economic development of the regions with the presence of a mining enterprise (use of crowdsourcing, to show concern for the health of employees, to promote the growth of social stability);

- developing management measures (automation of mining operations, development of corporate culture).

Further researches need a system of indicators for the DPSIR framework, which can be used as the basis for providing information support for an analytical study of the introduction of sustainable development by mining companies.

This work was conducted within the projects "Scientific basics to form unified system to preserve and generate power of the objects of fuel and energy complex of Ukraine" (State registration No. 0117U001127) and "Scientific substantiation and development of energy saving and low waste technologies of hydrocarbon and mineral raw materials extraction" (State registration No. 0116U008041).

\section{References}

1. Fischer-Kowalski, M., \& Swilling, M. (2011). Decoupling natural resource use and environmental impacts from economic growth. A Report of the Working Group on Decoupling to the International Resource Panel. Switzerland: United Nations Environment Programme.

2. Shapar, A.H. (2001). Problemy staloho rozvytku i zabezpechenist pryrodnymy resursamy. Collection of scientific works of the Institute of Natural Resources and Ecology of the NAS of Ukraine, (3), 7-23.

3. Litvak, O.A. (2015). Dekaplinh-analiz ekonomichnoho zrostannia ta ratsionalnoho silskohospodarskoho zemlekorystuvannia v ahrarnomu sektori. Naukovyi Visnyk Khersonskoho Derzhavnoho Universytetu, (15), 40-43.

4. Pivniak, H.H., Pilov, P.I., Pashkevych, M.S., \& Shashenko, D.O. (2012). Synchro-mining: Civilized solution of problems of mining regions' sustainable operation. Naukovyi Visnyk Natsionalnoho Hirnychoho Universytetu, (3), 131-138. 
5. Veklych, O.O. (2000). Formuvannia ekonomichnoho mekhanizmu staloho rozvytku Ukrainy. Visnyk Natsionalnoi Akademii Nauk Ukrainy, (2), 3-16.

6. Herasymchuk, Z.V. (2001). Rehionalna polityka staloho rozvytku: metodolohiia formuvannia, mekhanizmy realizatsii. Lutsk: Nadstria.

7. Strategic directions of transition of Ukraine to the principles of sustainable development in the context of its integration into the European Community (2005). Kyiv: Saliutys.

8. Kulibaka, N.A. (2002). Sushchnost i faktory ekonomicheskoy ustoychivosti predpriyatiya. Retrived from: http://uran.donntu.org/ masters/2002/fem/kulbaka/lib/s13.htm

9. Pivnyak G.G., Shashenko, O.M. (2015). Innovations and safety for coal mines in Ukraine. Naukovyi Visnyk Natsionalnoho Hirnychoho Universytetu, (6), 118-121.

10. Vasilenko, V.A. (2011), Organizacionno-ciklicheskaya i strukturno-funkcionalnaya modeli razvitiya organizatsii. Kul'tura narodov Prichernomor'ya, (232), 100-107.

11. Kasych, A.O. (2011). Teoretychni i metodychni osnovy analizu vnutrishnikh dzherel finansuvannia. Actual Problems of Economics, (117), 243-250.

12. Ericsson, M (2012). Mining technology - trends and development. Polinares working paper. POLINARES Consortium.

13. Bondar-Podhurska O.V. (2014). Naukovo-metodychni aspekty innovatsiinoho rozvytku hirnychodobuvnoi promyslovosti v konteksti staloho zrostannia. Naukovyi Visnyk Natsionalnoho Hirnychoho Universytetu, (1), 143-152.

14. Vagonova, O.G., Volosheniuk, V.V. (2012). Mining enterprises' economic strategies as derivatives of nature management in the system of social relations. Naukovyi Visnyk Natsionalnoho Hirnychoho Universytetu, (2,) 127-134

15. Danylyshyn, B.M., \& Veklych, O O. (2008). Efekt dekaplinhu yak faktor vzaiemozviazku mizh ekonomichnym zrostanniam i tyskom na dovkillia. Visnyk Natsionalnoi Akademii Nauk Ukrainy, (5), 12-18.

16. Tur, O.M. (2012). Ekonomichne obhruntuvannia stratehii ekoloho oriientovanoho rozvytku natsionalnoi ekonomiku. PhD Thesis. Sumy, Ukraine: SumDU.

17. Akulov, A.O. (2013). Effekt dekaplinga v industrialnom regione (na primere Kemerovskoy oblasti). Ekonomicheskie i sotsyal'nye peremeny: fakty, tendentsii, prognozy, (4), 177-185.

18. Jackson, T. (2009). Prosperity without Growth: Economics for a Finite Planet. Washington, United States: Earthscan. https://doi.org/10.1260/0958-305X.22.7.1013

19. Tereshchenko, M.O. (2016). Hirnycha promyslovist. Entsyklopediia suchasnoi Ukrayinu. Kyiv: IEDNANU.

20. Trubetskoy, K.N. (2011). Problemy i perspektivy razvitiya gornykh nauk. Marksheyderiya $i$ nedropolzovanie, (2), 9-12.

21. State Fiscal Service of Ukraine. (2019). The Office of Large Taxpayers of the State Fiscal Service. Available at: http://officevp.sfs.gov.ua

22. Kasych A.O., \& Tkachenko, I.V. (2011). Vidminnosti vstanovlennia finansovoho rezultatu v bukhhalterskomu ta podatkovomu oblikakh. Actual Problems of Economics, (116), 185-191.

23. Derzhavna sluzhba statystyky Ukrainy. Industry of Ukraine in 2011-2015: Statistical Yearbook. Available at: http://www.ukrstat.gov.ua

24. Ministerstvo ekolohii ta pryrodnykh resursiv Ukrainy (2017). Natsionalna dopovid pro stan navkolyshnoho pryrodnoho seredovyshcha v Ukraini u 2015 rotsi. Kyiv: FOP Hrin’ D.S.

25. Deloitte. (2016). Tracking the trends 2017. The top 10 trends mining companies will face in the coming year. Available at: https://www2.deloitte.com/global/en/pages/energy-andresources/articles/tracking-the-trends.html

26. S\&P Global Market Intelligence. (2018). Industry Top Trends 2018: Metals and Mining. Available at: https://pages.marketintelligence.spglobal.com/mining-industry-outlook-2018$\underline{\text { MS.html }}$ 
27. Vehmas, J., Malaska, P., Luukkanen, J. et al. (2003). Europe in the global battle of sustainability: Rebound strikes back. Advanced Sustainability Analysis. Turku School of Economics and Business Administration. Series Discussion and Working Papers, (7), 127-135.

28. Tapio, P. (2005). Towards a theory of decoupling: degrees of decoupling in the EU and the case of road traffic in Finland between 1970 and 2001. Transport Policy, 12(2), 137-151. https://doi.org/10.1016/j.tranpol.2005.01.001

29. OECD Environmental indicators (2003). Development, measurement and use. Reference paper. Available at: http://www.oecd.org/env/indicators-modelling-outlooks/24993546.pdf

30. UNEP. (2011). Decoupling Natural Resource Use and Environmental Impacts from Economic Growth. Available at: http://wedocs.unep.org/handle/20.500.11822/9816

31. Thematic Strategy on the Sustainable Use of Natural Resources. (2005). Retrived from: http://eurlex.europa.eu/LexUriServ/LexUriServ.do?uri=COM: 2005:0670:FIN:EN:PDF

32. Statistical Annual of Ukraine for 2016. (2017). Kyiv: August Trade.

33. State Statistics Service of Ukraine. (2018). Kvartalni rozrakhunky valovoho vnutrishnoho produktu Ukrainy za 2010-2017 roky. Available at: http://officevp.sfs.gov.ua http://ukrstat.gov.ua/druk/publicat/kat_u/2018/zb/05/zb_krvvpu2017pdf.pdf

34. State Statistics Service of Ukraine. (2018). Statistical Yearbook of Ukraine for 2017. Available at: http://www.ukrstat.gov.ua/druk/publicat/kat_u/2018/zb/08/Ukr_cifra_2017_u.pdf

35. OECD. (2001). Environmental Indicators: A Preliminary Set. Available at: http://www.oecd.org/site/worldforum/33703867.pdf

36. Posadzki, A. (2016). Mining firm uses crowdsourcing to identify potential gold deposits. Waterloo Region Record. Retrived from: http://therecord.com/news-story/6373045-mining-firmuses-crowdsourcing-to-identify-potential-gold-deposits/

37. Van Olphen, H. (1963). An introduction to clay colloid chemistry. New York, United States: Interscience Publishers, Div. of John Wiley \& Sons. https://doi.org/10.1002/jps.2600530238

38. Teck. (2016). SunMine Solar Farm Project at Sullivan Site. Available at: http://www.teck.com/news/stories/2015/sunmine-solar-farm-project-at-the-sullivan-site

39. Bardas, A.V. (2009). Prychyny i ekoloho-ekonomichni naslidky zakryttia shakht. Ekonomichnyi Visnyk Natsionalnoho Hirnychoho Universytetu, (3), 88-95.

40. Kasych, A., \& Vochozka, M. (2019). The Choice of Methodological Approaches to the Estimation of Enterprise Value in Terms of Management System Goals. QUALITY Access to Succes, (169), 3-9. 